\title{
Aldosterone Synthase Deficiency Type 2
}

National Cancer Institute

\section{Source}

National Cancer Institute. Aldosterone Synthase Deficiency Type 2. NCI Thesaurus. Code C126815.

Aldosterone synthase deficiency characterized by decreased conversion of 18hydroxycorticosterone to aldosterone. 